\title{
Late Eocene to middle Miocene (33 to 13 million years ago) vegetation and climate development on the North American Atlantic Coastal Plain (IODP Expedition 313, Site M0027)
}

\author{
U. Kotthoff ${ }^{1}$, D. R. Greenwood ${ }^{2}$, F. M. G. McCarthy ${ }^{3}$, K. Müller-Navarra ${ }^{1}$, S. Prader ${ }^{1}$, and S. P. Hesselbo \\ ${ }^{1}$ Institut für Geologie, Centrum für Erdsystemforschung und Nachhaltigkeit, Universität Hamburg, \\ Bundesstraße 55, 20146 Hamburg, Germany \\ ${ }^{2}$ Department of Biology, Brandon University, 270 18th Street, Brandon, Manitoba, R7A 6A9, Canada \\ ${ }^{3}$ Department of Earth Sciences, Brock University, 500 Glenridge Avenue, St. Catharines, Ontario, L2S 3A1, Canada \\ ${ }^{4}$ Camborne School of Mines, College of Engineering, Mathematics and Physical Sciences, University of Exeter, Penryn \\ Campus, Treliever Road, Penryn, Cornwall TR10 9FE, UK
}

Correspondence to: U. Kotthoff (ulrich.kotthoff@uni-hamburg.de)

Received: 8 November 2013 - Published in Clim. Past Discuss.: 13 December 2013

Revised: 30 April 2014 - Accepted: 3 July 2014 - Published: 25 August 2014

\begin{abstract}
We investigated the palynology of sediment cores from Site M0027 of IODP (Integrated Ocean Drilling Program) Expedition 313 on the New Jersey shallow shelf to examine vegetation and climate dynamics on the east coast of North America between 33 and 13 million years ago and to assess the impact of over-regional climate events on the region. Palynological results are complemented with pollenbased quantitative climate reconstructions. Our results indicate that the hinterland vegetation of the New Jersey shelf was characterized by oak-hickory forests in the lowlands and conifer-dominated vegetation in the highlands from the early Oligocene to the middle Miocene. The Oligocene witnessed several expansions of conifer forest, probably related to cooling events. The pollen-based climate data imply an increase in annual temperatures from $\sim 11.5^{\circ} \mathrm{C}$ to more than $16^{\circ} \mathrm{C}$ during the Oligocene.

The Mi- 1 cooling event at the onset of the Miocene is reflected by an expansion of conifers and mean annual temperature decrease of $\sim 4{ }^{\circ} \mathrm{C}$, from $\sim 16^{\circ} \mathrm{C}$ to $\sim 12{ }^{\circ} \mathrm{C}$ around 23 million years before present. Relatively low annual temperatures are also recorded for several samples during an interval around $\sim 20$ million years before present, which may reflect the Mi-1a and the Mi-1aa cooling events. Generally, the Miocene ecosystem and climate conditions were very similar to those of the Oligocene. Miocene grasslands, as known from other areas in the USA during that time period, are not
\end{abstract}

evident for the hinterland of the New Jersey shelf, possibly reflecting moisture from the proto-Gulf Stream.

The palaeovegetation data reveal stable conditions during the mid-Miocene climatic optimum at $\sim 15$ million years before present, with only a minor increase in deciduousevergreen mixed forest taxa and a decrease in swamp forest taxa. Pollen-based annual temperature reconstructions show average annual temperatures of $\sim 14{ }^{\circ} \mathrm{C}$ during the midMiocene climatic optimum, $\sim 2{ }^{\circ} \mathrm{C}$ higher than today, but $\sim 1.5^{\circ} \mathrm{C}$ lower than preceding and following phases of the Miocene. We conclude that vegetation and regional climate in the hinterland of the New Jersey shelf did not react as sensitively to Oligocene and Miocene climate changes as other regions in North America or Europe due to the moderating effects of the North Atlantic. An additional explanation for the relatively low regional temperatures reconstructed for the mid-Miocene climatic optimum could be an uplift of the Appalachian Mountains during the Miocene, which would also have influenced the catchment area of our pollen record.

\section{Introduction}

The Eocene to Miocene witnessed the transition from warmer "greenhouse" to colder "icehouse" conditions (Zachos et al., 2001a, 2008) and a decreasing global sea level 
(e.g. Miller et al., 2005). These changes did not occur gradually or continuously, but with several reversals to warmer conditions, as well as short phases of rapid cooling (e.g. Zachos et al., 2001a; DeConto et al., 2008). These changes and their driving factors are mainly understood from marine climate records, while examinations integrating terrestrial proxies remain rare (e.g. Eldrett et al., 2009, 2014; Pross et al., 2012). This is particularly the case for eastern North America, whereas several integrated studies for Eurasia have been published during the last 2 decades (e.g. Mosbrugger et al., 2005; Jiménez-Moreno et al., 2005, 2007; Larsson et al., 2011; Quaijtaal et al., 2014).

The transition from the late Eocene to the Oligocene is characterized by a rapid global cooling (the "Oi-1 event") and the onset of large-scale Antarctic ice sheet growth, as indicated by $\delta^{18} \mathrm{O}$ increases in marine sediments from different localities (e.g. Shackleton and Kennet, 1975; Miller et al., 1987; Liu et al., 2009). For the terrestrial realm, the results are few and contradictory: some terrestrial records show almost no climatic changes (Grimes et al., 2005) and only weak faunal reactions (Prothero and Heaton, 1996) during the transition, while others imply increased aridity, cooling (Zanazzi et al., 2007), and increased seasonality (Eldrett at al., 2009). The distribution of global vegetation changed significantly during the early Oligocene, with retreat of the tropical and paratropical biomes to the lower latitudes and an equatorward expansion of temperate vegetation (e.g. Wolfe, 1992, Leopold et al., 1992, Janis, 1993, Willis and McElwain, 2002). In the Northern Hemisphere, including North America, broad-leaved forests declined, and conifer forests migrated southwards (Janis, 1993). Several Oligocene shortterm sea-level and climate fluctuations, sometimes called Oi events (e.g. Miller et al., 1991; Wade and Pälike, 2004), were probably tied to the orbital cycles, as shown by, e.g. Coxall et al. (2005), Wade and Pälike (2004), and Pälike et al. (2006). The late Oligocene was a time of global warming and retreat of ice sheets in Antarctica (Zachos et al., 2001a, 2008).

The transition to the Miocene was characterized by a strong cooling pulse, the Mi-1 event (Miller et al., 1987, 1991; Wright and Miller, 1992; Zachos et al., 2001b). Subsequently, starting at $\sim 20$ million years before present (Ma), global temperatures increased, culminating in the mid-Miocene climatic optimum (MMCO) between $\sim 17$ and $\sim 14 \mathrm{Ma}$ (Zachos et al., 2001b). This overall warm interval was, however, interrupted and followed by several centennial-scale cooling events, e.g. further Mi events (Miller et al., 1987, 1991; Pagani et al., 1999) associated with growth of the Antarctic ice sheet, which also influenced the North Atlantic realm (e.g. Miller et al., 1991; Quaijtaal et al., 2014) and caused a relative sea-level fall of e.g. $\sim 60 \mathrm{~m}$ in the New Jersey shelf area (Miller et al., 2011). Furthermore, the early Miocene witnessed the spread of biomes dominated by grasses (Poaceae; Jacobs et al., 1999; Willis and McElwain, 2002; Strömberg, 2005). This spread and the loss of forest cover during the Miocene may have weakened the bi- otic weathering feedback (Taylor et al., 2009) and thus contributed to the climate development from the Miocene until today (Pagani et al., 2009).

The MMCO was followed by a gradual cooling and ice sheet expansion during the late Miocene, while atmospheric $\mathrm{CO}_{2}$ remained relatively stable compared to Eocene to early Miocene oscillations (Pagani et al., 2005). This cooling trend and increasing seasonality is generally reflected in pollen records from fluvial deposits from the middle Atlantic margin (Pazzaglia et al., 1997), but these records could only be correlated roughly with marine records. Pollen-based results for the same region presented by Groot (1991) are somewhat contradictory, indicating stable climate conditions at the close of the Miocene. However, the records described by Groot (1991) lack consistent age models and can thus not be compared directly with other climate archives.

In short, there remains a lack of studies that integrate changes in the marine realm (e.g. sea-surface water temperatures and sea-level changes) with vegetation and climate developments in the terrestrial realm during the Eocene, Oligocene and Miocene. The impact of cooling events like the Oi-1- and the Mi-1 events or of the MMCO on vegetation and regional climate in eastern North America has not yet been assessed.

An ideal approach for studies integrating marine and terrestrial ecosystem and climate changes is the examination of terrestrial and marine palynomorphs in long marine cores (e.g. Heusser and Shackleton, 1979; Eldrett et al., 2009, 2014; Pross et al., 2012; Contreras et al., 2013). Methods have been developed to calculate quantitative climate data (e.g. temperature, precipitation, and seasonality) from pollen assemblages. One of these methods is the "nearest-livingrelative" (NLR)/“co-existence" or "mutual climate range" (MCR) method (e.g. Mosbrugger and Utescher, 1997; Pross et al., 2000; Thompson et al., 2012; Reichgelt et al., 2013; Eldrett et al., 2014): climatic limits of fossil plant taxa are assumed to be similar to those of their nearest living relatives. Therefore, the intervals of climate parameters for a given fossil flora, in which a maximal number of nearest relatives can coexist, can be considered the best possible description of the palaeoclimate under which the fossil flora lived (Thompson et al., 2012). The relative abundances of the analysed taxa are not considered in the NLR method only their presence and absence. This makes the climate reconstructions less susceptible to transport-related and taphonomic bias. Taphonomic skewing of the palynological record can be used to interpret variations in terrigenous sediment influx into the marine realm, and can furthermore be used to reconstruct site-shoreline distances and sea-level fluctuations (e.g. McCarthy and Mudie, 1998; McCarthy et al., 2013), but differential preservation and transport characteristics of pollen taxa can hamper ecosystem- and climate reconstructions, altering the original pollen associations. These taphonomic problems can however be minimized/controlled by (a) choosing research areas characterized by high sedimentation 
rates where oxidation of palynomorphs is less pronounced, either due to lower dissolved oxygen or rapid burial (e.g. Kotthoff et al., 2008a, b) sites sufficiently proximal to the coastline to minimize transportation bias (e.g. Mudie and McCarthy, 1994) and reduce the probability of re-sedimentation by choosing neritic sites (e.g. McCarthy and Mudie, 1998; Hopkins and McCarthy, 2002; McCarthy et al., 2004); and (c) sedimentary settings that have remained tectonically stable.

These criteria have largely been met in the New Jersey shallow shelf area (NJSS; North American east coast, Fig. 1; Mountain et al., 2010). The potential of this region for palaeoclimate research and for sea-level reconstruction has already been shown for records from the coastal plain and the continental slope (Miller and Sugarman, 1995; Miller et al., 1996). Cores recovered from the NJSS in the framework of IODP (Integrated Ocean Drilling Program) Expedition 313 in 2009 (Fig. 1, Supplement Fig. S1) allow study of the palaeovegetation and palaeoclimate development in coastal studying eastern North America during certain intervals of the Oligocene and particularly the Miocene. In context of IODP Expedition 313 a robust age model was developed based on palaeontological, sedimentological, and geochemical data (Browning et al., 2013; Miller et al., 2013). Here, we present a new pollen record from Site M0027 from the New Jersey shelf which covers the interval from $\sim 33$ to $\sim 13 \mathrm{Ma}$. While our record does not allow a continuous overview over this complete time span, it offers several insights into shorter intervals, including the Oligocene-Miocene transition and the mid-Miocene climatic optimum. With this record, we can reconstruct a longer history of the vegetation and climate development during the Oligocene and Miocene than obtained from previous palynomorph-based examinations for coastal eastern North America.

\section{Geographical and geological setting}

Hole M0027A was drilled into the New Jersey shallow shelf at $39^{\circ} 38.046^{\prime} \mathrm{N}$ and $73^{\circ} 37.301^{\prime} \mathrm{W}$ at $33.5 \mathrm{~m}$ water depth and a site-shoreline distance of $\sim 50 \mathrm{~km}$ (Fig. 1). Total penetration reached 631 meter below seafloor (mbsf), with a recovered interval of $547 \mathrm{~m}$. The hole was aimed at sampling a thick early Miocene succession, but relatively thin and incomplete Pleistocene, middle to late Miocene and Oligocene sediments were also recovered (Mountain et al., 2010). The Oligocene/Miocene sediment record from the New Jersey shallow shelf is characterized by several sedimentary sequences tied to transgression and regression phases (e.g. Mountain et al., 2010; Browning et al., 2013; Miller et al., 2013; Fang et al., 2013). Ages of these sequences are discussed in Sect. 3.1. The succession below $420 \mathrm{mbsf}$ was deposited mainly by mass wasting beyond the shelf break during glacioeustatic lowstands. The succession above $360 \mathrm{mbsf}$, however, has accumulated on the shelf dur- ing highstands, and thus should not be prone to substantial resedimentation (McCarthy et al., 2013).

The palaeogeographic position of the research area has slightly changed since the late Eocene. Reconstructions by Scotese et al. (1988) imply that during the Oligocene and Miocene, the region of New Jersey was situated $\sim 2^{\circ}$ further south than at present, and reached a position between $39^{\circ}$ and $40^{\circ} \mathrm{N}$ during the Pliocene. Prevailing westerly winds transported pollen from the Atlantic Coastal Plain as they do today. These winds also currently push the Gulf Stream offshore, allowing polar surface currents to penetrate between the Gulf Stream and northeastern North America as far south as Cape Hatteras (Csanady and Hamilton, 1988). Although the modern North Atlantic Slope Water mass appears to have originated only $\sim 1.4 \mathrm{Ma}$ (McCarthy et al., 2000), a low salinity (but warmer) precursor to this water mass appears to have been created by abundant fluvial runoff since the Gulf Stream originated, separating northeastern North America from the warm, saline subtropical gyre, and thus resulting in greater seasonality than in the oceanic realm. The time of the origin of the Gulf Stream remains hotly debated, but there is evidence of strong current activity on the Blake Plateau as early as the late Paleocene-early Eocene (Pinet et al., 1981) and it was an intense western boundary current by the latest Miocene, when it experienced its greatest intensification based on deep erosion of the Blake Plateau (Kaneps, 1979). The palaeogeographic reconstructions of Scotese et al. (1988) for $20 \mathrm{Ma}$ suggest that the North and South Equatorial currents blown by the easterly trade winds would largely have recirculated northward in the Atlantic rather than continuing to the Pacific Ocean via the highly restricted seaway between the Americas, consistent with the sedimentary evidence from the Blake Plateau (Pinet et al., 1981).

The modern annual precipitation in the coastal regions of New Jersey is $\sim 1100 \mathrm{~mm}$, and average annual temperatures are $\sim 12^{\circ} \mathrm{C}$ (climate.rutgers.edu/stateclim/) with a warm, moist tropical airstream originating in the Gulf of Mexico producing a warm and humid climate east of the Pacific frontal zone that transports moisture-depleted air past the Rocky Mountains (Bryson and Hare, 1974). Grasslands occupy the semi-arid interior of North America west of this frontal zone, while the oak-pine-hickory forest of Davis and Webb (1975) is found where the Gulf Stream hugs the coastline and oak-pine forests (deciduous forest of Davis and Webb, 1975) are found north of Cape Hatteras, where seasonality is much greater. Tectonic uplift of the Appalachian Highlands during the middle Miocene (e.g. Poag et al., 1989; Pazzaglia and Brandon, 1996; Gallen et al., 2013) increased the altitudinal gradient, promoting the expansion of conifers at higher elevations, as characterises the region today (Delcourt et al., 1984). 


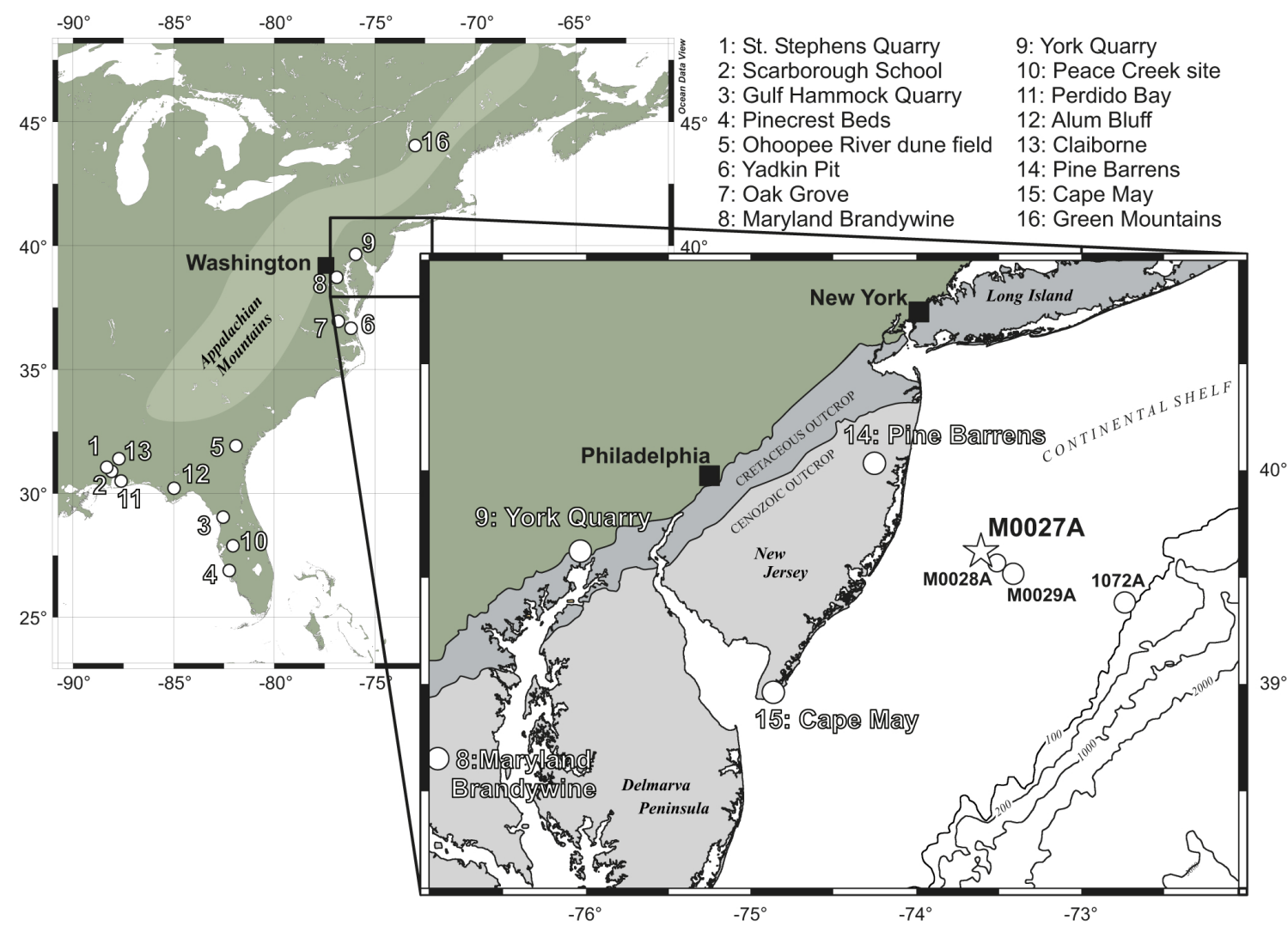

Figure 1. Map of eastern North America with a zoom into the area around New Jersey. White points indicate plant macrofossil outcrops, pollen profiles, and drilling sites referred to (1: Oboh et al., 1996; 2, 10, 11: e.g. Stults et al., 2010; 3, 8, 12: e.g. Jarzen et al. 2010; 4: Hansen et al., 2001; Jarzen and Dilcher, 2006; 5: Rich et al., 2002; 6: Groot, 1991; 7: Frederiksen, 1991; 9: Pazzaglia et al., 1997; 13, 14, 15: e.g. Rachele 1976; 16: Traverse, 1994) and the white star indicates the position of Site M0027 (after Mountain et al., 2010; Schlitzer, 2011). Black squares mark the position of major cities.

\section{Material and Methods}

\subsection{Age model}

We used the age model of Browning et al. (2013) to assign ages to samples from Hole M0027A. The precision of the age model based on integrated microfossil biostratigraphy (dinoflagellate cysts, diatoms, calcareous nannofossils), strontium isotopes, and sequence stratigraphy (Browning et al., 2013; Miller et al., 2013) varies: for the Oligocene, the potential error is between 0.5 and $1.0 \mathrm{Ma}$, while for the early Miocene, the potential error is below $0.5 \mathrm{Ma}$. The uncertainty is particularly high ( 1 to $1.5 \mathrm{Ma}$ ) for the upper sequences (m5 to m1; Supplement Fig. S1) deposited during the middle Miocene (between $\sim 14$ and $\sim 11 \mathrm{Ma}$ ). However, Site M0027 yields sediments from the very early $\mathrm{Ru}-$ pelian to the late Priabonian $(\sim 33.7$ to $\sim 32.2 \mathrm{Ma}$; sequence O1) and continuous records for the late Rupelian $(\sim 29.3$ to $\sim 28.2 \mathrm{Ma}$; sequences $\mathrm{O} 3$ to O5), interrupted by a pronounced hiatus during the early Rupelian (32.2 to $29.3 \mathrm{Ma}$ ). There is another pronounced hiatus during the Chattian. The sediment record from Site M0027 furthermore comprises the very late Chattian, including the transition to the Aquitanian $(\sim 23.5$ to $\sim 23 \mathrm{Ma}$; sequence O6), the early Burdigalian ( $\sim 20.9$ to $\sim 19.2 \mathrm{Ma}$, sequences $\mathrm{m} 6$ and $\mathrm{m} 5.8)$, and, with some shorter hiatuses, the late Burdigalian to Serravallian $(\sim 18$ to $\sim 11.6 \mathrm{Ma}$; subsequent sequences; Browning et al., 2013; Miller et al., 2013). The sequences are also shown in Figs. 2, 3, and 4, as well as in Supplement Fig. S1.

Processing and counting: sediments of approximately $\sim 5 \mathrm{~cm}^{2}$ volume $/ \sim 8 \mathrm{~g}$ dry weight were processed for palynological analysis at Brock University using standard techniques, including treatment with warm, diluted $(0.02 \%)$ sodium hexametaphosphate, weak $(10 \%) \mathrm{HCl}$ and concentrated (40\%) HF, and sieving through Nitex mesh to retain the $>15 \mu \mathrm{m}$ fraction. Lycopodium spore tablets were added in order to calculate pollen concentrations (Stockmarr, 1971). Palynomorphs were identified at $400 \times / 500 \times / 1000 \times$ magnification using a Zeiss Axio Scope.

Sixty-one samples from Site M0027 were analyzed for their palynomorph content. For most samples, between 200 and 300 non-saccate pollen grains (NSPGs) and between 250 and 400 pteridophyte spores, non-saccate pollen, and saccate pollen grains (in total) have been counted. In case of three 


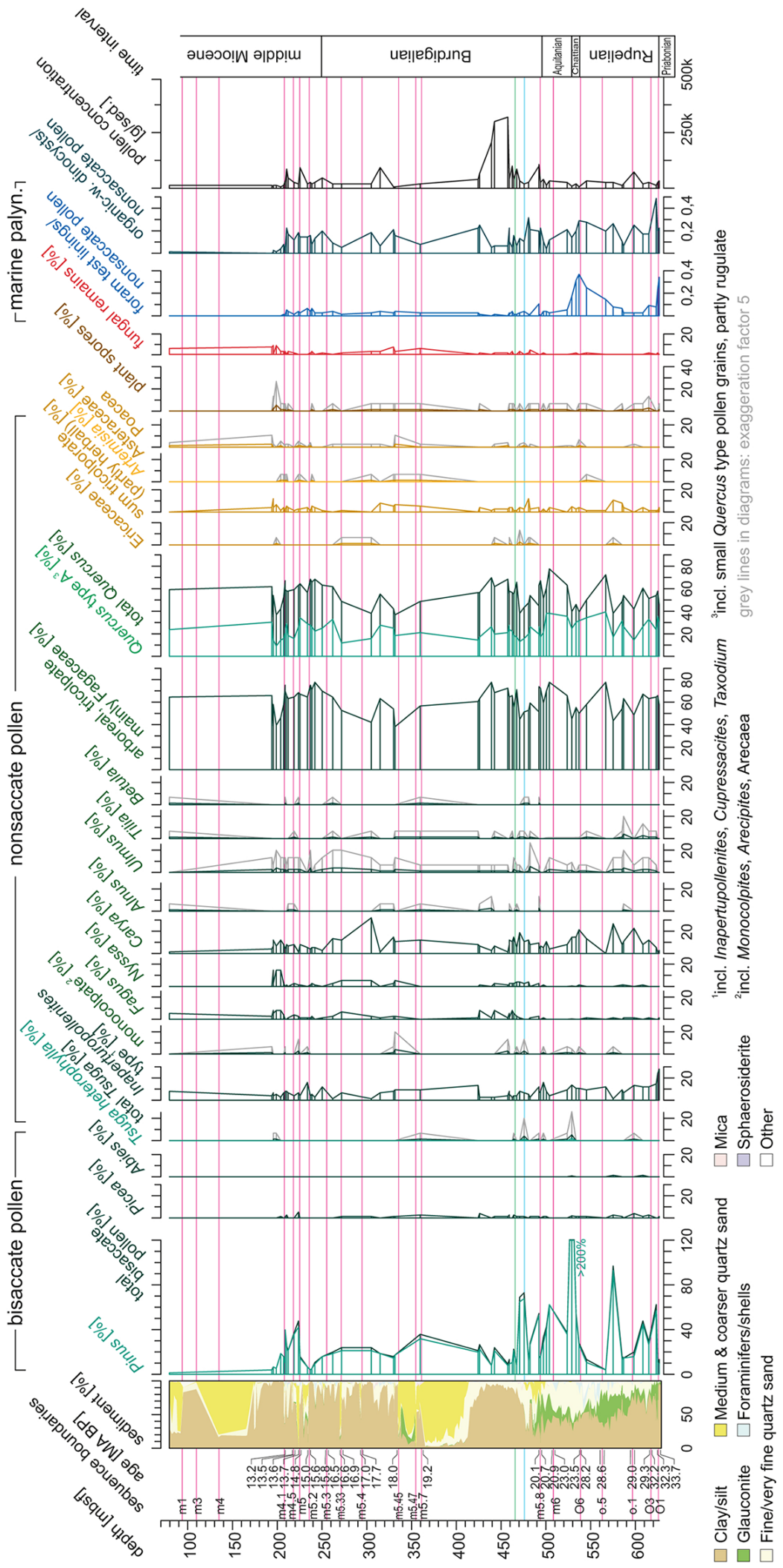

Figure 2. Sedimentological and palynological results for Site M0027. Shown versus depth: lithology; sequence boundaries; selected pollen types, pteridophyte spores and fungal remains (taxa $<1 \%$ excluded; percentages are based on the sum of non-saccate pollen); marine palynomorphs (marine palyn.): foraminifer test lining/nonsaccate pollen ratio, organic-walled dinoflagellate cyst/non-saccate pollen ratio; pollen concentration (for some samples, the weight was estimated based on the sample volume), time intervals. For taxa with low occurrences, exaggeration lines $(\times 5)$ are shown in grey. Sequence ages are based on Browning et al. (2013). 


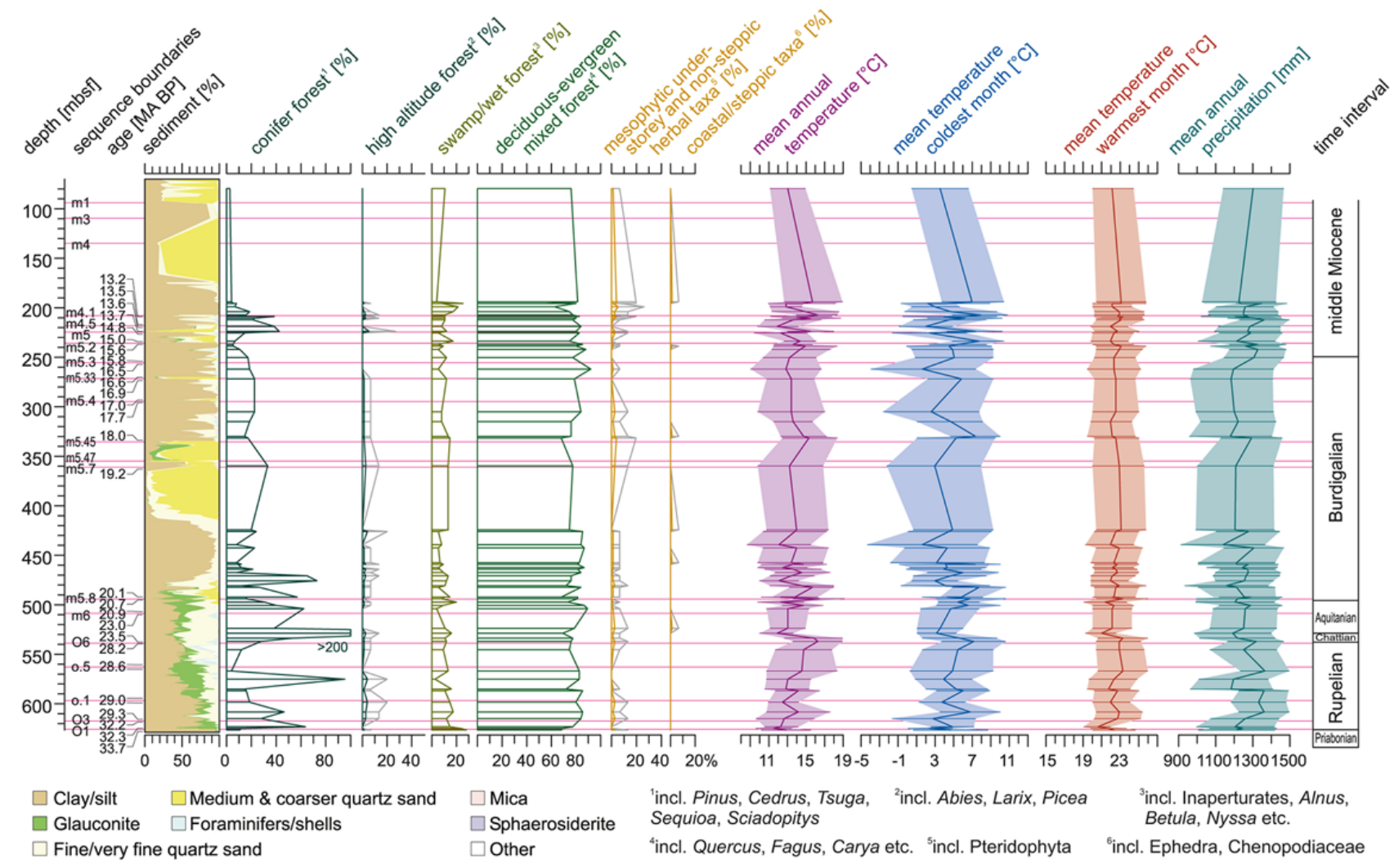

Figure 3. Lithology, palynological results, and pollen-based climate results for Site M0027. Shown versus depth: lithology, sequence boundaries, pollen percentages integrated into vegetation types (percentages are based on the sum of non-saccate pollen), pollen-based quantitative climate data, time intervals. Sequence ages are based on Browning et al. (2013).

samples, the pollen sum was between 140 and 200 grains. In addition to pollen grains and pteridophyte spores, fungal remains, foraminifer test linings (forams), and dinoflagellate cysts (dinocysts) were counted. We used the total number of NSPGs as reference sums for all percentage calculations (Figs. 2 and 3). The data used for this study will be stored in the PANGEA database (www.pangea.de).

\subsection{Assessment of palynomorph associations and pollen differentiation}

A detailed review of the marine and terrestrial palynology at Site M0027 and Site M0029, is given by McCarthy et al. (2013). This study showed that in sequences preceding sequence 5.8 (i.e. older than $\sim 20.1 \mathrm{Ma}$; Supplement Fig. S1, Fig. 2), sediments primarily reached Site M0027 by mass wasting during glacioeustatic lowstands, influencing pollen assemblages, and thus hampering detailed palaeovegetation reconstructions based on relative occurrences. Considering these findings, we have excluded samples from intervals characterized by mass waste events and reworking at Site M0027 for which a strong bias due to transport effects was indicated (McCarthy et al., 2013). For the remaining samples analysed in our study, reworking of pollen and transport- related bias within non-saccate pollen assemblages should be a minor issue.

Due to the particularly efficient airborne transport, longer floating time in the water column, and high resistance to oxidation, bisaccate pollen is generally over-represented in marine pollen assemblages and shows significant relative increase compared to other pollen types with increased distance from the coastline (e.g. Mudie, 1982; Hooghiemstra, 1988; Mudie and McCarthy, 1994; McCarthy et al., 2003). It has been shown that terrestrial modern pollen assemblages in eastern North America, including coastal and continental shelf sediments, reflect the modern vegetation with exception of the genera Pinus (pine) and Picea (spruce), whose bisaccate pollen often originate from very distant regions (e.g. Davis and Webb, 1975; Mudie, 1982). In light of this, we have excluded bisaccate pollen from the reference sum on which pollen percentage calculations are based. However, high percentages of bisaccate pollen, e.g. Pinus pollen, are not necessarily tied to transport effects; they can still be related to climate-based changes in the catchment area and to extension of Pinus forests onto shelfal areas during sealevel lowstands (Lacourse et al., 2003; Kotthoff et al., 2008a). Herein, we use estimates of the site-shoreline distance based on the ratio of marine palynomorphs (dinocysts, forams) to 


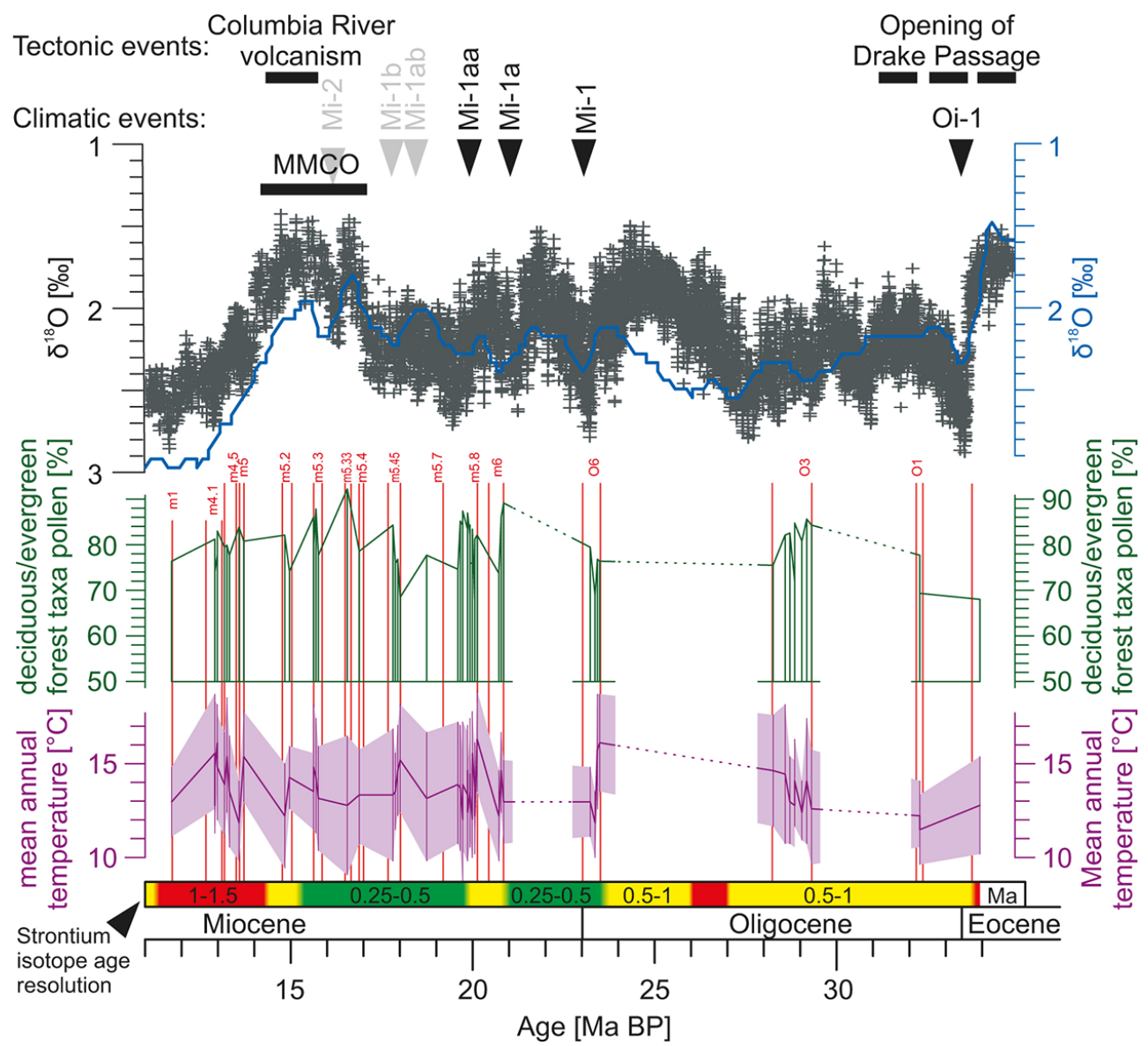

Figure 4. Pollen-based mean annual temperature reconstruction and deciduous-evergreen forest taxa pollen percentages for Site M0027 vs. age compared to a stacked and smoothed oxygen-isotope record from the Pacific (after Cramer et al., 2009), global oxygen-isotopes after Zachos et al. (2001a, 2008), and global events (position of Mi events after Miller et al., 1991; Pekar and DeConto, 2006). Age model for Site M0027 after Browning et al. (2013) and Miller et al. (2013). Strontium isotope age resolution after Browning et al. (2013); green: 0.25 to $0.5 \mathrm{Ma}$, yellow: 0.5 to $1.0 \mathrm{Ma}$, red: > 1.0 Ma.

NSPGs to validate the relevance of high bisaccate-pollen percentages, assuming that over-representation of bisaccate pollen is lower in samples with small relative abundances of dinocysts and foraminifer test linings.

For pollen identification, we used several works of Krutzsch (1963a, b, 1967, 1970, 1971) and also descriptive publications and pollen keys of, e.g. McAndrews et al. (1973), Frederiksen $(1979,1980)$, Traverse (1994), Pazzaglia et al. (1997), Beug (2004), and Jarzen et al. (2010). Generally, we have assigned pollen grains to extant taxa (compare Supplement Table S2).

We have counted pollen of Podocarpus (i.e. Podocarpidites) separately; however, it should be noted that Podocarpus grains are very similar to Pinus grains and cannot be distinguished in all cases. Both genera contain several species that are very variable in pollen morphology, and the palynomorph Podocarpidites includes both "Podocarpus" as well as Pinus (Nichols and Brown, 1992), and may also represent related genera in the Podocarpaceae and not Podocarpus sensu strictu (Greenwood et al., 2013). Arecipites, other Arecaceae, and the "Monocolpopollenites type" were counted separately, but grouped together as "monocolpate" for the pollen diagram (Fig. 2). The differentiation of Arecipites-, Monocolpopollenites- and Liliacidites-related pollen grains is a matter of debate, e.g. there is uncertainty concerning the presence of Arecipites grains with reticulate structure (compare Krutzsch, 1970, Nichols, 1973). We have followed the approach of Krutzsch (1970) and in some cases assigned monocolpate grains with a fine reticulate structure (compare Supplement Fig. S2) to Arecipites, but grains with a reticulum formed of clearly visible clavae and baculae were assigned to Liliacidites (e.g. Nichols, 1973). Generally, the morphology of Arecaceae pollen grains is highly diverse (e.g. Harley and Baker, 2001). Grains assigned to "other Arecaceae" were mainly monocolpate, in rare cases monoporate. Our conservative approach to identifying palm pollen in the New Jersey record may have yielded cooler temperature 
estimates for some samples due to palms being not identified as such, but as Liliacidites.

For the current study and the pollen diagram presented in Fig. 2, we have assigned Quercus-type pollen grains to two groups, with Quercus type A containing smaller and sometimes rugulate grains in contrast to bigger, never regulate grains. Information on differentiation criteria for further taxa (e.g. Tsuga, Ulmus, Taxodium) is given in the supplementary material.

\subsection{Vegetation types}

To analyze changes in ecosystems in the hinterland of the New Jersey shelf, we have assigned the pollen and spores encountered in this study to groups based on the modern ecology of related genera (Fig. 3; Supplement Table 1), following similar approaches of, e.g. Jiménez-Moreno et al. (2005) and Larsson et al. (2011). While we have not assigned the same taxa to different vegetation types, several of the taxa mentioned in Supplement Table 1 can occur in different ecosystems. For example, Nyssa (tupelo tree) is present within several vegetation types in recent southeastern North America; however, Nyssa is particularly frequent in swamp associations due to its tolerance of wet soils and is therefore best placed into the swamp forest vegetation type. Similarly, $\mathrm{Cu}$ pressaceae, including Taxodium, occur in a variety of environments, but the majority of North American species rather prefer wet conditions and include swamp taxa. Generally, the assignment to vegetation types allows a clearer interpretation of the pollen data and comparison with other palaeobotanical records.

\subsection{Quantitative climate reconstructions}

Climate was reconstructed by applying bioclimatic analysis (as modified by Greenwood et al., 2005; Reichgelt et al., 2013), a form of "nearest living relative" (NLR) analysis (Mosbrugger and Utescher, 1997) or mutual climate range (MCR) technique (Thompson et al., 2012) to the spore-pollen record of land vegetation. Spore and pollen taxa with known NLR were identified from the fossil assemblages. Climatic profiles were then assembled from both published and unpublished sources for each NLR with respect to various climate parameters such as mean annual temperature (MAT), coldest month mean temperature (CMMT), warmest month mean temperature (WMMT), and mean annual precipitation (MAP). Each profile contains the maximum and minimum values for a range of climate and related environmental variables with respect to an individual NLR taxon, based on their present-day distribution. For this study, the majority of climate profiles were obtained from Thompson et al. (1999, 2000, 2012) and Fang et al. (2011) for trees and shrubs, and the online database of Natural Resources Canada (2012) for non-trees, supplemented by data from sources outlined in Eldrett et al. (2014).
To determine the climate envelope that accommodated a majority of taxa from a given fossil assemblage with respect to a given climate parameter, the zone of overlap was calculated using the 10th percentile (as lower limit) and 90th percentile (as upper limit) of the total range for all NLRs represented in that sample (Greenwood et al., 2005; Reichgelt et al., 2013; Eldrett et al., 2014). This calculation removes or down-weights outliers, i.e. NLR taxa whose climate profile is at the extremes of the range of all taxa in the assemblage and is comparable to the weighted MCR method of Thompson et al. (2012). The estimate in bioclimatic analysis is presented as the midpoint between the lower and upper limits, with the error spanning from the lower to the upper limit (Greenwood et al. 2005; Pross et al., 2012; Thompson et al., 2012; Reichgelt et al., 2013). With this approach and by using mainly the climate profiles from Thompson et al. (1999, 2000, 2012), we avoid problems discussed by Grimm and Denk (2012), who showed that MAT ranges provided for NLR in the widely used PALAEOFLORA database (www.palaeoflora.de) are partly inaccurate and that the precision reached with the coexistence approach based on this database is low. Thompson et al. (2012), however, demonstrated that for modern North American and Pleistocene vegetation assemblages; (1) there was a high degree of correlation between observed climatic values (including CMMT and MAT) and estimates from MCR approaches, (2) estimates with sample NLR $\leq 10$ were much less precise than for samples where $n \sim 20 \mathrm{NLR}$, and (3) presence-absence comparisons versus those based on taxon abundance avoid assumptions of fossil and modern vegetation being analogous. Their analysis also showed that MCR analysis of modern eastern North American coniferous forests and broadleaf forests $\left(30-47^{\circ} \mathrm{N}\right)$ yielded accurate and precise temperature estimates. All of our samples had at least 17 NLRs with climate profiles for our analysis, with the majority of the samples analysed with 20 or more NLRs with climate profiles. Whereas genera are typically used for NLRs in bioclimatic analysis (e.g. Reichgelt et al., 2013), in the present analysis Tsuga was differentiated by species. Picea and Pinus pollen was excluded from the reconstructions due to their overrepresentation in marine pollen records as also done by Eldrett et al. (2009, 2014), whereas Podocarpus was excluded due to concerns over the correct botanical affinity of these grains (Greenwood et al., 2013, compare Sect. 3.3).

Thompson et al. (2012) demonstrated that the extremes of the modern climate range (i.e. $0 \%$ and $100 \%$ ) of NLRs yield wide climate estimates and so recommended assigning the 10th and 90th percentiles to the range of climatic tolerance of plant genera to increase precision. The weighting (i.e. exclusion of outliers) in bioclimatic analysis (sensu Greenwood et al., 2005) based on the 10th and 90th percentiles yields a warm estimate where a predominance of taxa with high minima are present, and a predominance of taxa with low minima yields a cool estimate. Particularly high temperature reconstructions in the 
bioclimatic analysis were therefore tied to the occurrence of thermophilic taxa such as palms (Arecaceae/Arecipitespollen type; Arecaceae MAT $11.2-28.9^{\circ} \mathrm{C}$, CMMT $2.1-$ $27.2^{\circ} \mathrm{C}$ ), together with mesothermic taxa with only moderate tolerance of cold winters (e.g. Nyssa MAT $4.5-23.0^{\circ} \mathrm{C}$, CMMT $-10.4-18.9^{\circ} \mathrm{C}$ ), whereas samples with notably cool estimates lacked these taxa (or contained only a few) and were rich in taxa with low winter tolerances (e.g. Alnus MAT $-12.2-20.9^{\circ} \mathrm{C}, \mathrm{CMMT}-30.9-14.1^{\circ} \mathrm{C}$, Fraxinus MAT $-2.3-24.4^{\circ} \mathrm{C}, \mathrm{CMMT}-23.8-18.1^{\circ} \mathrm{C}$ ).

\section{Results}

\subsection{Quantitative palynology}

\subsubsection{7 to 540 mbsf, Eocene (Priabonian)?, Oligocene (Rupelian, $\sim 33$ to $\sim 28 \mathrm{Ma}$ )}

The relative amount of marine palynomorphs (depicted in foram/NSPG ratio and dinocyst/NSPG ratio, Fig. 2) shows a decreasing trend from $\sim 627$ to $\sim 580 \mathrm{mbsf}$ and a subsequent increasing trend up to $\sim 538 \mathrm{mbsf}$ (sequence boundary O6). Bisaccate pollen generally shows a very similar trend of decreasing abundance. Notable exceptions are two samples at $\sim 626$ and $\sim 624$ mbsf with very low bisaccate pollen percentages (paired with relatively high percentages of swamp taxa pollen; Fig. 3 ) and one sample at $\sim 576$ mbsf with particularly high Pinus percentages. The sample at $\sim 576 \mathrm{mbsf}$ is furthermore characterized by very low pollen percentages of swamp taxa and increased herbaceous pollen percentages. Pollen of deciduous-evergreen forest taxa show percentages varying between 67 and $86 \%$. Dominant pollen taxa in this association are Quercus (oak) and Carya (hickory) and, to a lower degree, Ulmus (elm) and Tilia (linden). Increases in Carya pollen are often coupled with decreases in Quercus, Ulmus, and Tilia pollen and vice versa.

\subsection{2 $\sim 540$ to $\sim 509 \mathrm{mbsf}$, Oligocene/early Miocene (late Chattian to early Aquitanian, $\sim 28$ to $\sim 23 \mathrm{Ma}$ )}

The sediments between $\sim 540$ and $\sim 509$ mbsf probably represent the time interval from $\sim 23.4$ to $\sim 23 \mathrm{Ma}$ and thus the transition from the late Chattian to the Aquitanian. This interval is represented by four samples in our record. The third of these samples (from below) shows a high peak of bisaccate pollen $(>200 \%)$, while marine palynomorphs do not show such high values. The high percentages of bisaccate (namely Pinus) pollen are paired with occurrences of Tsuga (hemlock) pollen, relatively high Carya pollen percentages and a significant decrease in pollen of other arboreal taxa (particularly Quercus, Tilia, Ulmus). Furthermore, this interval contains the only Oligocene sample where steppic taxa reach relative occurrences of at least $\sim 1 \%$, paired with rela- tively high abundances (around 2\%) of the "mesophytic understorey and non-steppic herbal taxa" group.

\subsection{3 $\sim 509$ to $\sim 422 \mathrm{mbsf}$, early Miocene (Aquitanian/early Burdigalian, 21 to $\sim 19 \mathrm{Ma}$ )}

This interval consists of two sequences (m6, m5.8) with sediments characterized by high content of pollen (Fig. 2). The foram/NSPG ratio is generally low, while the dinocyst/NSPG ratio varies and reaches up to $\sim 0.3$. There are occurrences of Tsuga pollen surpassing $2 \%$ of the non-saccate pollen assemblage at $\sim 475 \mathrm{mbsf}$. This relative increase in Tsuga pollen is expressed to a higher degree at site M0029 (around $\sim 733 \mathrm{mbsf} / \sim 20.1 \mathrm{Ma}$, with almost $10 \%$ of nonsaccate pollen; Supplement Fig. S1). A similar peak is also revealed at Site M0028A at a depth of $\sim 620 \mathrm{mbsf}$ (Supplement Fig. S1; Mountain et al., 2010). For all sites, the hemlock peak is coeval with a strong increase in bisaccate pollen (mainly Pinus, at $\sim 475$ to $\sim 470 \mathrm{mbsf}$ at Site M0027), but a minor increase in the dinocyst/NSPG ratio (Fig. 2).

Generally, Pinus shows a decreasing trend for this interval. The Pinus pollen increase around $475 \mathrm{mbsf}$ is coeval with an increase in Carya (over $18 \%$ ), Ericaceae, and Nyssa pollen, while members of the family Fagaceae, including Quercus, show a significant decrease from $\sim 79$ to $\sim 45 \%$. Between $\sim 467$ and $\sim 423 \mathrm{mbsf}$, there are still minor fluctuations in the pollen percentages of single taxa, but the percentages of combined deciduous-evergreen forest taxa remain relatively stable.

The pollen record also reveals occurrences of rare deciduous tree taxa such as Juglans and Corylus. Pollen concentration is particularly high around $\sim 450 \mathrm{mbsf}$, while the number of marine palynomorphs is particularly low in the same interval. The interval from $\sim 410$ to $\sim 365 \mathrm{mbsf}$ at Site M0027, consisting of medium to coarse-grained sand, is barren of palynomorphs.

\subsection{4 $\sim 360$ to $\sim 260 \mathrm{mbsf}$, early Miocene (late Burdigalian $\sim 19$ to $\sim 16.5 \mathrm{Ma}$ )}

This interval is represented by seven samples in the pollen record from Site M0027. It is the first phase containing consistent occurrences of Poaceae (grass) pollen, but the percentages never exceed $2.5 \%$ for all samples analyzed. During this interval, the percentages of different taxa (particularly Fagaceae, Carya, Nyssa) within the deciduousevergreen mixed forest group vary significantly, while the combined percentages show a weak increasing trend of $\sim 10 \%$. The second half of the interval is characterized by a significant increase in Quercus and a decrease in Carya pollen percentages. 


\subsection{5 $\sim 250$ to $\sim 79$ mbsf, middle Miocene (Langhian/Serravallian, Tortonian? $\sim 16$ to $\sim 11.6 \mathrm{Ma})$}

Nineteen samples from Site M0027 represent the interval between $\sim 16$ and $\sim 11.6 \mathrm{Ma}(\sim 250$ to $\sim 80 \mathrm{mbsf})$ in our pollen record. Between $\sim 250$ and $\sim 199$ mbsf $(\sim 16$ to $\sim 13 \mathrm{Ma}$ ), Quercus/Fagaceae pollen and combined pollen percentages of deciduous-evergreen mixed forest taxa decrease. Samples from $\sim 199 \mathrm{mbsf}$ to $\sim 190 \mathrm{mbsf}$ show strong variation in pollen percentages of deciduous-evergreen forest taxa (Fig. 4). In addition to relatively frequent Ulmus (elm) pollen, the sediments between $\sim 250$ and $\sim 79 \mathrm{mbsf}$ also contain small amounts of Tilia, Alnus, Carpinus, and Ostrya pollen grains. The samples between $\sim 210$ and $\sim 190 \mathrm{mbsf}$ reveal a decrease of conifer (mainly Pinus) pollen and strong increase in fungal remains.

The uppermost sample (from sequence $\mathrm{m} 1 ; \sim 79.6 \mathrm{mbsf}$ ) probably has an age of $\sim 11.6 \mathrm{Ma}$ (J. V. Browning, personal communication, 2012). This sample is not particularly different from older Miocene samples and is characterized by low percentages of bisaccate pollen and marine palynomorphs, and also high percentages of fungal remains.

\subsection{Pollen-based climate reconstructions}

Pollen-based temperature values are generally well constrained for the record from Site M0027, with uncertainties varying between 2 to $4{ }^{\circ} \mathrm{C}$ for mean annual temperatures (Fig. 3). Mean temperatures of the warmest month generally show less variation between samples than those of the coldest month. The mean annual precipitation curve for Site M0027 is less variable than the reconstructed temperatures. The values vary between $\sim 1140$ and $\sim 1370 \mathrm{~mm} \mathrm{a}^{-1}$, which is within the range of the values encountered today in New Jersey.

Relatively warm temperatures are indicated for the lowermost, probably Priabonian-aged sample (MAT: $\sim 13^{\circ} \mathrm{C}$, CMMT: $\sim 5^{\circ} \mathrm{C}$ ). MAT values for the subsequent sample from the early Oligocene are lower by $1.2^{\circ} \mathrm{C}$, CMMT values are $2.3^{\circ} \mathrm{C}$ lower. During the Oligocene, MAT values show a generally increasing trend, culminating in particularly high values of $\sim 16^{\circ} \mathrm{C}$ for two samples around $\sim 535 \mathrm{mbsf}$ ( 23.4 MA). MAP reconstructions indicate generally more humid conditions during the Rupelian than during the following intervals with exception of two samples at depth of $\sim 585$ and $\sim 576$ mbsf. The high temperature values during the late Oligocene are followed by a rapid decline to $\sim 12{ }^{\circ} \mathrm{C}$ at the transition to the early Miocene ( $\sim 530$ mbsf; Fig. 4).

For the time interval reflected in sequence $\mathrm{m} 6$ and the lower part of m5.8 ( $\sim 503$ to $\sim 439 \mathrm{mbsf}$; reflected in 18 samples), average MATs of $\sim 14{ }^{\circ} \mathrm{C}$ have been reconstructed, showing a slight decreasing trend. Samples reflecting particularly cool conditions around $\sim 12^{\circ} \mathrm{C}$ are re- vealed at $\sim 475 \mathrm{mbsf}(\sim 20 \mathrm{Ma}), \sim 462 \mathrm{mbsf}(19.9 \mathrm{Ma})$, and at $\sim 439 \mathrm{mbsf}(\sim 19.7 \mathrm{Ma})$.

Reconstructions for the interval from $\sim 18 \mathrm{Ma}$ to $\sim 16.6 \mathrm{Ma}(\sim 335$ to $\sim 250 \mathrm{mbsf})$ reveal a cooling trend to MATs of $\sim 13^{\circ} \mathrm{C}$ with a minimum at $\sim 262 \mathrm{mbsf}$. At the end of this interval, MAP reconstructions indicate more humid conditions which prevail until $\sim 11 \mathrm{Ma}$. Between $\sim 16$ to $14.5 \mathrm{Ma}$ ( $\sim 255$ to $\sim 225 \mathrm{mbsf})$, MAT values vary significantly between $\sim 12^{\circ} \mathrm{C}$ to $\sim 15^{\circ} \mathrm{C}$. The subsequent time interval ( $\sim 14.5$ to $\sim 12 \mathrm{MA}$; $\sim 225$ to $\sim 80 \mathrm{mbsf}$ ) shows slightly higher average MAT $\left(\sim 14.5^{\circ} \mathrm{C}\right)$, with peak values $\left(>16^{\circ} \mathrm{C}\right)$ at $\sim 13 \mathrm{MA}$ (around $\sim 208 \mathrm{mbsf}$ ). Samples indicating relatively low temperatures during this interval are positioned at depths of $\sim 218 \mathrm{mbsf}$ (13.6 Ma) and of $\sim 199 / 196 \mathrm{mbsf}(\sim 12.9 \mathrm{Ma})$.

\section{Discussion and comparison with other vegetation records}

In the following, we present an interpretation of the vegetation and climate development in the hinterland of the New Jersey shelf, integrating the relative abundances of terrestrial and marine palynomorphs and the pollen-based quantitative climate analyses with further results from IODP Expedition 313. The results and interpretations are compared with other records from the North Atlantic, eastern/central North America, and Europe, and with global climate records, particularly oxygen-isotope records.

\subsection{Eocene(?), Oligocene (Rupelian, $\sim 33$ to $\sim 28 \mathrm{Ma}$ )}

For the lowermost two samples analysed $(\sim 627$ and $\sim 624 \mathrm{mbsf}$ ), high relative abundances of marine palynomorphs, particularly foraminifer test linings, compared to non-saccate pollen, imply a particularly long site-shoreline distance. Under such circumstances, bisaccate pollen should be particularly over-represented. The very low percentages of bisaccate pollen in these samples thus imply that conifer forests were rare in the catchment area of Site M0027 or very far away from the site during the very late Eocene/very early Oligocene. It cannot be unambiguously determined whether the lowermost sediments from Site M0027 are from the Priabonian or the early Oligocene (Browning et al., 2013). But if the lowermost sample analyzed herein is of Priabonian age, then the temperature changes over the Eocene-Oligocene boundary in hinterland of the New Jersey shelf (with a decrease in MAT of $1.2^{\circ} \mathrm{C}$ and $2.3^{\circ} \mathrm{C}$ in CMMT) are weaker than changes found by Eldrett et al. (2009), who calculated a decrease of annual temperature of $\sim 3^{\circ} \mathrm{C}$ (from $\sim 13$ to $\sim 10^{\circ} \mathrm{C}$ ) at the transition from the Eocene to the Oligocene in the high latitudes, based on the NLR method applied to sediments from the Norwegian-Greenland Sea. Similarly to the findings of Eldrett et al. (2009), Liu et al. (2009) showed 
that sea-surface temperatures decreased by $\sim 5^{\circ} \mathrm{C}$ in the high latitudes at the Eocene-Oligocene transition.

The relatively minor changes in pollen associations (excluding a strong decrease in swamp/wet forest taxa, Fig. 3) between the samples at $\sim 627$ and $\sim 624$ mbsf indicate that air temperature may have been a less important controlling factor for vegetation development at that time and only influenced particular thermophilous species. This is consistent with results of Oboh et al. (1996), who also could not find significant palaeobotanical changes at the Eocene-Oligocene boundary in records from southeastern North America (including St. Stephens Quarry, Fig. 1, No. 1), while marine proxies at St. Stephens Quarry indicate significant changes in the marine ecosystems.

The decreasing trend in marine palynomorphs from $\sim 627$ to $\sim 580$ mbsf $(\sim 33$ to $\sim 28.8 \mathrm{Ma}$; Fig. 2$)$ indicates a shortening site-shoreline distance, with a subsequent lengthening of the distance up to $\sim 538 \mathrm{mbsf}$, which is coeval with increasing MATs. A relatively dry phase during a generally humid interval with MAP below $1200 \mathrm{~mm}$ is indicated for $\sim 28.8 \mathrm{Ma}$ by two samples, of which the second also indicates a spread of conifers and a decrease of swamp forest vegetation.

Generally, the vegetation in the catchment area was dominated by oak-hickory (Quercus-Carya) forests (with changing frequency of elms and lindens). While Alnus (alder) is common in western and northern North American records from the Eocene and Oligocene, its presence in Oligocene sediments from southeastern North America has to our knowledge not yet been confirmed, and evidence from the Eocene is rare. Alnus pollen was identified by Gray (1960) in Eocene sediments from Alabama (Fig. 1, No. 13), but Frederiksen (1979) found Alnus pollen in Palaeocene, but not Eocene samples in Virginia (Oak Grove, Fig. 1, No. 7), and studies from the Eocene of Florida (Jarzen and Dilcher, 2006; Fig. 1, No. 3) did not reveal the presence of this genus. Swamp vegetation was widespread during the late Eocene and the early Oligocene, but less abundant during the following interval between $\sim 29.3$ and $\sim 28.2 \mathrm{Ma}$.

\subsection{Oligocene/Miocene transition (late Chattian/early Aquitanian, 23 Ma)}

The findings described in Sects. 4.1.2 and 4.2 indicate that the time interval from $\sim 23.4$ to $\sim 23 \mathrm{Ma}(\sim 535$ to $\sim 523 \mathrm{mbsf}$ ) was characterized by warm temperatures and a long site-shoreline distance, but a sudden cooling (Fig. 4) by $\sim 4{ }^{\circ} \mathrm{C}$ (MAT) led to an expansion of conifer forests, including a spread of Tsuga. The Tsuga pollen grains found within this interval probably belong to different species $(T$. canadensis, T. heterophylla, and T. mertensiana). These findings are consistent with phylogenetic results by Havil et al. (2008), implying that the split of these species occurred during the Eocene/Oligocene. The increase in Tsuga pollen is of particular interest since this genus, particularly Tsuga het- erophylla, can tolerate cool climates, but needs humidity and cannot tolerate persistent drought (e.g. Havill et al., 2008). As temperatures dropped at $\sim 23.4 \mathrm{Ma}$, the site-shoreline distance shortened, as indicated by the decrease in marine palynomorph/NSPG ratios, particularly in the foram/NSPG ratio (Fig. 2). This temperature drop and shortening of the site-shoreline distance is probably linked to the Mi-1 glacial event (see Sect. 5.6) and the accompanying sea-level fall.

\subsection{Early Miocene (Aquitanian/early Burdigalian, 21 to $\sim 19 \mathrm{Ma})$}

The frequent occurrences of Tsuga pollen at all three sites around $\sim 20 \mathrm{Ma}(\sim 492$ and $\sim 475 \mathrm{mbsf}$ at Site M0027, Suppl. Fig. S1 and Fig. 3), paired with very high percentages of Pinus pollen (at Site M0029 at around 733 mbsf and at Site M0028A at a depth of $\sim 620 \mathrm{mbsf}$ ) may be partly caused by over-representation due to the good transport properties of these pollen types - particularly given the location beyond the clinoform rollover at all three sites. Nonetheless, considering the coeval decrease in deciduous-evergreen forest, we infer that around $\sim 20$ Ma cooler, but humid conditions prevailed in the hinterland of the New Jersey shelf, causing a spread of conifer taxa in the catchment area. MAP values of $\sim 1240 \mathrm{~mm}$ around this interval compared to lower averaged values of $\sim 1200 \mathrm{~mm}$ (Fig. 4) during the middle and lower Burdigalian support this scenario. The cool conditions indicated for $\sim 20 \mathrm{Ma}, \sim 19.9 \mathrm{Ma}$, and $\sim 19.7 \mathrm{Ma}$ may be related to Mi-events (see below). The presence of Fagus and Juglans in the area is confirmed by findings of respective pollen grains in the early Miocene Brandon lignite from Vermont, an area north of New Jersey (Traverse, 1994; Fig. 1, No. 16).

The site-shoreline distance probably continued to shorten during the related interval between $\sim 20$ and $\sim 19.5 \mathrm{Ma}$ as implied by decreasing abundances of marine palynomorphs. Using also foraminifer-based water-depth calculations, McCarthy et al. (2013) infer a generally falling sea level for this interval.

\subsection{Early Miocene (late Burdigalian $\sim 19$ to $\sim 16.5 \mathrm{Ma}$ )}

The relatively weak changes in the ratios between marine palynomorphs and NSPGs over this interval $(\sim 360$ to $\sim 269 \mathrm{mbsf}$ ) point to only minor changes in the siteshoreline distance, while at almost the same time, starting at $\sim 18 \mathrm{Ma}$, the hinterland of the NJSS witnessed a decrease of MATs by $\sim 2.5^{\circ} \mathrm{C}$. Due to slight uncertainties in the age model (0.25 to 0.5 Ma, Browning et al., 2013; Fig. 4), it is unclear if the particularly low MAT values at $\sim 262 \mathrm{mbsf}$ are the regional reflectance of the Mi-2 event (e.g. Miller et al., 1991). The weak increase in combined deciduous-evergreen mixed forest taxa with a relative decrease of Carya (hickory) presence during the second half of this interval (starting at $\sim 17.9 \mathrm{Ma}$ ) may indicate increasingly humid conditions, 
which is also partly reflected in the quantitative climate data. These indicate a significant increase of MAP starting with the onset of the MMCO (at $\sim 16.6 \mathrm{Ma} / 262 \mathrm{mbsf}$ ).

The occurrences of Poaceae pollen indicate that grasses were present within the vegetation in the Atlantic Coastal Plain during the early Miocene, but our pollen record implies that they never became an important factor during the time interval examined in the framework of this study. There are only a few intervals during the subsequent middle Miocene during which Poaceae showed slightly higher abundances. The generally rare occurrences of true grasses in the Atlantic coastal plain can be explained with the consistent humid conditions in the catchment area, presumably tied to the presence of the proto-Gulf Stream since at least the early Eocene (Pinet et al., 1981).

\subsection{Middle Miocene (Langhian/Serravallian, $\sim 16$ to $\sim 11.6 \mathrm{Ma})$}

Generally, the pollen assemblages found in the middle Miocene sediments from Site M0027 ( 250 to $\sim 79 \mathrm{mbsf}$ ) are very similar to those found in the neighbouring pollen record from the York Quarry (Fig. 1, No. 9) with Quercus, Carya, and Pinus being dominant taxa, and the consistent presence of Taxodiaceae, Cupressaceae, Ulmus, Ilex, Liquidambar, Pterocarya, and Castanea-like pollen (Pazzaglia et al., 1997). The Langhian/Serravallian pollen percentages and pollen-based climate reconstructions from Site M0027 imply several changes in ecosystems, particularly spreads in swamp forests and understorey plants. Similarly, climate conditions varied significantly.

The similarity of the sample at $\sim 79.6$ mbsf to the Miocene samples below indicates that it is also of Miocene age. The relatively high MATs $\left(\sim 13.2^{\circ} \mathrm{C}\right)$ for this sample fit well with palaeoflora-based estimations from New Jersey (Pine Barrens; Fig. 1, No. 14). The Miocene palaeoflora suggests warm and temperate conditions for this region at $\sim 11 \mathrm{Ma}$ (Greller and Rachele, 1984). Based on the palynoflora, Rachele (1976) estimated the annual precipitation to $1270 \mathrm{~mm}$, average January temperature to $6^{\circ} \mathrm{C}$ and average July temperature to $24^{\circ} \mathrm{C}$. These results cannot directly be tied to the record from Site M0027 due to the lack of precise age estimations for the Miocene lignite analysed in the study of Rachele (1976), but they match relatively well with our results for the sample at $\sim 79.6 \mathrm{mbsf}$ (MAP: $\sim 1305 \mathrm{~mm}$, CMMT: $\sim 3.0^{\circ} \mathrm{C}$, WMMT: $\sim 22.2^{\circ} \mathrm{C}$ ). Our results are furthermore consistent with findings by McCartan et al. (1990) who analyzed a late Miocene palaeoflora from upland deposits of the southern Maryland Coastal Plain (Fig. 1, No. 8). The climate was probably warmer in southeastern North America. Palaeobotanical records from the middle Miocene Alum Bluff Flora (Fig. 1, No. 12) indicate warm-temperate conditions (e.g. Jarzen et al., 2010).
The plant associations found in early/middle Miocene sediments (reflecting the MMCO and the subsequent interval) from the NJSS are very similar to those encountered in similar-aged marine/marginal marine sediments from Atlantic Western Europe (e.g. Larsson et al., 2011). However, the MATs reconstructed for the Miocene of the Atlantic Coastal Plain (averaged MAT to $\sim 13.7^{\circ} \mathrm{C}$ for the interval from $\sim 16.5$ to $\sim 14 \mathrm{Ma}$ and $\sim 14.3^{\circ} \mathrm{C}$ thereafter) are colder by $\sim 1$ to almost $4{ }^{\circ} \mathrm{C}$ compared to records from Denmark $\left(\sim 17.5^{\circ} \mathrm{C}\right.$, Larsson et al., 2011$)$, Serbia $\left(\sim 15.5^{\circ} \mathrm{C}\right.$, Utescher et al., 2007), or Bulgaria $\left(\sim 15^{\circ} \mathrm{C}\right.$, Utescher et al., 2009), with European records from higher altitudes showing lower temperatures. Considering that the present-day MATs in the European regions mentioned above are significantly lower (e.g. $\sim 9^{\circ} \mathrm{C}$ in Denmark; $\sim 11^{\circ} \mathrm{C}$ in Serbia) than in New Jersey $\left(\sim 12^{\circ} \mathrm{C}\right.$, Sect. 2$)$, this seems to be a discrepancy, even considering that the palaeolatitudes of the European records were $\sim 5^{\circ}$ lower during the MMCO (e.g. Scotese et al., 1988).

\subsection{Further comparison with global signals and outlook}

The pollen-based quantitative climate record presented here for Site M0027 must remain fragmentary due to several hiatuses and the insufficient pollen preservation in coarsegrained sediments, even if the sample resolution will probably be increased during subsequent studies. The age model established by Mountain et al. (2010) and Browning et al. (2013) still allows a comparison with supra-regional climate records (Fig. 4).

If directly compared to global climate changes as indicated in oxygen-isotope values (Zachos et al., 2001a, 2008; Cramer et al., 2009), the averaged mean annual temperature record shows similar signals during the Palaeogene. The transition from the Priabonian to the early Oligocene is reflected in a temperature decrease (Fig. 4), but this decrease is weaker than in records from the high latitudes (Eldrett et al., 2009; Liu et al., 2009). Furthermore, a shift to less humid conditions is indicated by the decrease in swamp/wet forest taxa (Fig. 3), though the pollen-based precipitation reconstructions for the transition interval are not precise enough to reveal such a shift. Around $\sim 29 \mathrm{Ma}$, an increase in MATs is congruent with a slight decrease in the oxygen-isotope values. Unfortunately, the interval from 28 to $26 \mathrm{Ma}$ is not yet recovered from the NJSS, but the Mi-1 cooling event (Miller et al., 1987, 1991; Wright and Miller, 1992) is reflected by shifts in palaeovegetation (Figs. 2 and 3) and a rapid fall in MATs (Figs. 3 and 4; compare Sect. 5.2).

For the early Miocene, there are still congruencies between the results from the NJSS and the global marine signals (Fig. 4). We suggest that the several decreases in mean annual and winter temperatures (Figs. 3 and 4) for the interval between $\sim 21$ and $\sim 19$ Ma can be local expressions of the Mi-1a and Mi-1aa events (Pekar and DeConto, 2006). 
The MAT peak at $\sim 18 \mathrm{Ma}$ and the subsequent rapid decrease is also congruent with the oxygen-isotope data (Fig. 4).

However, for the interval between $\sim 17$ to $14.5 \mathrm{Ma}(\sim 272$ to $\sim 225$ mbsf at Site M0027), which should reflect the MMCO, the regional temperature signals from the NJSS and the global signal reflected in the benthic oxygen-isotope record seem to be decoupled (Fig. 4). The MAP values show a significant increase at the onset of the MMCO (at $\sim 16.5 \mathrm{Ma}$ ), but the MAP remain continuously high from there on, even after the end of the MMCO. The deciduousevergreen forest taxa pollen curve seems to some degree to resemble the oxygen-isotope curve, but the averaged MATs over the MMCO imply a temperature of only $\sim 14{ }^{\circ} \mathrm{C}$, (less than in preceding and subsequent intervals). The only minor impact on the North Atlantic Coastal Plain of North America is surprising, since the MMCO had a strong impact on the terrestrial realm on the eastern side of the North Atlantic (e.g. Mosbrugger et al., 2005; Quaijtaal et al., 2014; see also Sect. 5.5).

One possible explanation for the discrepancy between indications for warm climate during the MMCO in other records and hints to relatively cool temperatures in our record could be a problem in the age model. The strontium-isotopeand microfossil-based age control could be erroneous by 1 to $1.5 \mathrm{Ma}$ for the samples between $\sim 225$ and $\sim 190 \mathrm{mbsf}$ (sequences m5, m4.5, and 4.1; compare Sect. 3.1). If shifted by $1.5 \mathrm{Ma}$ to the past, the samples from these depths could reflect the second part of the $\mathrm{MMCO}$ at $\sim 15 \mathrm{Ma}$, since the pollen-based climate reconstructions imply particularly warm MAT for these samples. But even if this were correct, there would still be a discrepancy with the first part of the $\mathrm{MMCO}$ at $\sim 16.5 \mathrm{Ma}$. For this time, the age control is particularly good (Fig. 4; Browning et al., 2013).

Another possible explanation would be that the hinterland of the NJSS was not very susceptible to global climate changes during the middle Miocene due to the moderating effect of the North Atlantic in that region. Climate model results assessing differences between the MMCO interval and present-day conditions (e.g. Herold et al., 2011, 2012) show only minor differences between MMCO and presentday conditions for the eastern US coast (including the region around New Jersey), while the northern North American (Canadian) coast and the regions around the Gulf of Mexico reveal strong differences. However, the climate models used in the studies of Herold et al. $(2011,2012)$ also indicate minor changes for western Europe, which is not congruent with results from European pollen records showing very warm conditions during the middle Miocene (e.g. Mosbrugger et al., 2005; Utescher et al., 2007; Larsson et al., 2011; compare Sect. 5.5).

A further option to explain the surprisingly low temperatures reconstructed for the hinterland of the NJSS would be topographical changes resulting in regional vegetation and climate changes. Climate model results by Herold et al. (2009) imply for the Miocene that topographical lowering of high mountain ranges such as the Andes and the Tibetian plateau can significantly increase regional temperatures. Vice versa, an uplift of mountain ranges could cause a shift in vegetation and a temperature decrease. Poag and Sevon (1989), Pazzaglia and Brandon (1996), and Gallen et al. (2013) discuss an uplift phase of the Appalachian Highlands (Fig. 1) during the middle Miocene based on sedimentation rates at the U.S. Atlantic continental margin and on analyses from the Cullasaja River basin (Southern Appalachian Highlands). Since the Appalachians are close to the NJSS, a tectonic uplift - even if not resulting in a significant spread of high altitude forests in the catchment area - could cause a decrease and even emigration of thermophilous taxa. This could be a possible explanation for the surprisingly low temperatures reflected in our pollen.

The current research state probably does not allow a final interpretation. During future research, the Oligocene and Miocene palynomorph assemblages of Site M0027 will be analysed in a higher resolution. Particularly the interval covering the MMCO will be in the focus of further studies.

\section{Conclusions}

The Atlantic Coastal Plain was characterized by oak-hickory forest during the Oligocene and Miocene. The Oligocene witnessed several expansions of temperate conifer forest, which in some cases can be tied to cooling events. The transition between Oligocene and Miocene sediments at the NJSS is probably the regional expression of the Mi- 1 cooling event. It is reflected by an expansion of conifers and an annual temperature decrease of almost $3^{\circ} \mathrm{C}$ to $12.5^{\circ} \mathrm{C}$ around $23 \mathrm{Ma}$.

There was little change in terrestrial ecosystem and climate conditions between the Oligocene and the Miocene. The pollen associations found in Miocene sediments are generally congruent with results from other North American pollen records. An Oligocene/Miocene expansion of grasslands is not evident for the hinterland of the NJSS. The quantitative climate results for the Miocene are in accordance with other reconstructions from the Atlantic Coastal Plain, but comprise a longer time interval. Further Miocene cooling events could be identified, which could be regional expressions of the Mi-1a and Mi-1aa cooling events at around $\sim 20 \mathrm{Ma}$. While the mean annual temperatures in the region were generally warmer than today (around $\sim 14{ }^{\circ} \mathrm{C}$ ) during the Oligocene and Miocene, they were significantly lower than temperatures reconstructed for European records.

There is no clear expression of the MMCO reflected in the pollen record from the NJSS, and mean annual temperatures during the $\mathrm{MMCO}$ were not higher than during preceding and subsequent intervals. We conclude that vegetation and regional climate in the hinterland of the New Jersey shelf may not have reacted as sensitively to Oligocene and Miocene global forcing factors as other regions in North America or 
Europe. An additional explanation for the relatively low regional temperatures reconstructed for the MMCO could be an uplift of the Appalachian Mountains during the middle Miocene.

\section{The Supplement related to this article is available online at doi:10.5194/cp-10-1523-2014-supplement.}

Acknowledgements. We thank the entire IODP Expedition 313 Scientific Party for input, and the IODP staff for support. We thank M. Drljepan, R. Zanatta, V. Menke, K. Reichel, and S. Namyslo for their assistance with preparing and processing the samples, and during photographing. Discussions with C. Bjerrum, J. Browning, T. Donders, L. Fang, M. Katz, Y. Milker, K. Miller, and P. Sugarman are gratefully acknowledged. Input from K. Dybkjær and anonymous reviewers was very much appreciated and contributed to a significant condensing of the manuscript. The German Science Foundation supported the research (DFG project KO 3944/3-1 to U. Kotthoff). Funding was also provided by NSERC Discovery Grants to F. M. G. McCarthy and to D. R. Greenwood respectively. NERC supported work by S. P. Hesselbo. This research used samples and/or data provided by the Integrated Ocean Drilling Program (IODP).

Edited by: A. Haywood

\section{References}

Beug, H.-J.: Leitfaden der Pollenbestimmung für Mitteleuropa und angrenzende Gebiete, Verlag Dr. Friedrich Pfeil, München, 2004.

Browning, J. V., Miller, K. G., Barron, J., Katz, M. E., Kulhanek, D. K., McCarthy, F. M. G., Feigenson, M. D., Olsson, R. K., and Sugerman, P. J.: Chronology of Eocene-Miocene sequences on the New Jersey shallow shelf: Implications for regional, interregional, and global correlations, Geosphere, 9, 1-23, 2013.

Bryson, R. A. and Hare, F. K. (eds): Climates of North America, world survey of climatology 11, Elsevier, Amsterdam, 1974.

Contreras, L., Pross, J., Bijl, P.K., Koutsodendris, A., Raine, J.I., van de Schootbrugge, B., and Brinkhuis, H.: Early to middle Eocene vegetation dynamics at the Wilkes Land Margin (East Antarctica), Rev. Palaeobot. Palynol., 197, 119-142, 2013.

Cramer, B.S., Toggweiler, J. R., Wright, D., Katz, M. E., and Miller, K. G.: Ocean overturning since the Late Cretaceous: Inferences from a new benthic foraminiferal isotope compilation, Paleoceanography, 24, 1-14, 2009

Csanady, G. T. and Hamilton. P.: Circulation of Slopewater, Continental Shelf Research, 8, 568-624, 1988.

Davis, R. B. and Webb III, T.: The contemporary distribution of pollen in eastern North America: a comparison with the vegetation, Quat. Res., 5, 395-434, 1975

DeConto, R. M., Pollard, D., Wilson, P. A., Pälike, H., Lear, C. H., and Pagani, M.: Thresholds for Cenozoic bipolar glaciation, Nature, 455, 652-657, 2008.

Delcourt, P. A., Delcourt, H. R., and Webb III, T.: Atlas of Mapped Distribution of Dominance and Modern Pollen Percentages for
Important Tree Taxa of Eastern North America, AASP Contribution 14, 131 pp., 1984.

Eldrett, J. S., Greenwood, D. R., Harding, I. C., and Huber, M.: Increased seasonality through the Eocene to Oligocene transition in northern high latitudes, Nature, 459, 969-974, 2009.

Eldrett, J. S., Greenwood, D. R., Polling, M., Brinkhuis, H., and Sluijs, A.: A seasonality trigger for carbon injection at the Paleocene-Eocene Thermal Maximum, Clim. Past, 10, 759-769, doi:10.5194/cp-10-759-2014, 2014.

Fang, J., Wang, Z., and Tang, Z. (Eds.): Atlas of Woody Plants in China, Distribution and Climate, Vols. 1 \& 2, Higher Education Press, Beijing, and Springer-Verlag, Berlin, 1-1972, 2011.

Fang, L., Bjerrum, C., Hesselbo, S. P., Kotthoff, U., McCarthy, M. F. G., Huang, B., and Ditchfield, P. W.: Carbon-isotope stratigraphy from terrestrial organic matter through the Monterey Event, Miocene, New Jersey margin (IODP Expedition 313), Geosphere, 9, 1303-1318, 2013.

Frederiksen, N. O.: Paleogene sporomorph Biostratigraphy, Northeastern Virginia, Palynology 3, 129-167, 1979.

Frederiksen, N. O.: Sporomorphs from the Jackson Group (Upper Eocene) and adjacent strata of Mississippi and western Alabama Geol. Surv. Prof. Paper, 1084, 1980.

Frederiksen, N. O.: Midwayan (Paleocene) pollen correlations in the Eastern United States, Micropaleontology, 37, 101-123, 1991.

Gallen, S. F., Wegmann, K. W., Bohnenstieh, D. W. R.: Miocene rejuvenation of topographic relief in the southern Appalachians, GSA Today, 23, 4-10, 2013.

Gray, J.: Temperate Pollen Genera in the Eocene (Claiborne) Flora, Alabama, Science, 132, 808-810, 1960.

Greenwood, D. R., Archibald, S. B., Mathewes, R. W., and Moss, P. T.: Fossil biotas from the Okanagan Highlands, southern British Columbia and northeastern Washington State: climates and ecosystems across an Eocene landscape, Can. J. Earth Sci., 42, 167-185, 2005.

Greenwood, D. R., Hill, C. R., and Conran, J. G.: Prumnopitys anglica sp. nov. (Podocarpaceae) from the Eocene of England, Taxon 62, 565-580, 2013.

Greller, A. M. and Rachele, L. D.: Climatic limits of exotic genera in the Legler palynoflora, Miocene, New Jersey, USA, Rev. Palaeobot. Palynol., 40, 149-163, 1984.

Grimm, G. W. and Denk, T.: Reliability and resolution of the coexistence approach - A revalidation using modern-day data. Rev Palaeobot. Palynol., 172, 33-47, 2012.

Groot, J. J.: Palynological evidence for Late Miocene, Pliocene, and Early Pleistocene climate changes in the middle U.S. Atlantic Coastal Plain, Quaternary Sci. Rev., 10, 147-162, 1991.

Hansen, B. C. S., Grimm, E. C., and Watts, W. A.: Palynology of the Peace Creek site, Polk County, Florida. Geol. Soc. Am. Bull., 113, 682-692, 2001.

Harley, M. M. and Baker, W. J.: Pollen aperture morphology in Arecaceae: application within phylogenetic analyses, and a summary of the fossil record of palm-like pollen, Grana, 40, 45-77, 2001.

Havill, N. P., Campbell, C. S., Vining, T. F., LePage, B., Bayer, R. J., and Donoghue, M. J.: Phylogeny and Biogeography of Tsuga (Pinaceae) inferred from Nuclear Ribosomal ITS and Chloroplast DNA Sequence Data, Syst. Bot., 33, 478-489, 2008. 
Herold, N., You, Y., Müller, R. D., and Seton, M.: Climate model sensitivity to changes in Miocene paleotopography, Aust. J. Earth Sci., 56, 1049-1059, 2009.

Herold, N., Huber, M., and Müller, R. D.: Modeling the Miocene Climatic Optimum. Part 1 Land and Atmosphere, J. Climate, 24, 6353-6372, 2011.

Herold, N., Huber, M., Müller, R. D., and Seton, M.: Modeling the Miocene Climatic Optimum: Ocean circulation, Paleoceanography, 27, PA1209, doi:10.1029/2010PA002041, 2012.

Heusser, L. E. and Shackleton, N.: Direct Marine-Continental Correlation: 150000-Year Oxygen Isotope pollen record from the North Pacific, Science, 204, 837-838, 1979.

Hooghiemstra, H.: Palynological records from Northwest African marine sediments: a general outline of the interpretation of the pollen signal, Philos. Trans. R. Soc. Lond. B Biol. Sci., 318, 431449, 1988.

Hopkins, J. A. and McCarthy, F. M. G.: Postdepositional palynomorph degradation in Quaternary shelf sediments: a laboratory experiment studying the effects of progressive oxidation, Palynology, 26, 167-184, 2002.

Jacobs, B. F., Kingston, J. D., and Jacobs, L. L.: The origin of grass dominated ecosystems, Ann. Mo. Bot. Gard., 86, 590-644, 1999.

Janis, C. M.: Tertiary mammal evolution in the context of changing climates, vegetation and tectonic events, Annu. Rev. Ecol. Syst., 24, 467-500, 1993.

Jarzen, D. M. and Dilcher, D. L.: Middle Eocene terrestrial palynomorphs from the Dolime Minerals and Gulf Hammock Quarries, Florida, USA, Palynology 30, 89-110, 2006.

Jarzen, D. M., Corbett, S. L., and Manchester, S. R.: Palynology and paleoecology of the Middle Miocene Alum Bluff Flora, Liberty, Palynology 34, 261-286, 2010.

Jiménez-Moreno, G., Rodriguez, F. J., Pardo-Iguzquiza, E., Fauquette, S., Suc, J., and Muller, P.: High resolution palynological analysis in late early-middle Miocene core from the Pannonian Basin, Hungary: climate changes, astronomical forcing and eustatic fluctuations in the Central Paratethys, Palaeogeogr. Palaeoclimatol. Palaeoecol., 216, 73-97, 2005.

Jiménez-Moreno, G., Fauquette, S., Fauquette, S., Suc, J., and Aziz, H. A.: Early Miocene repetitive vegetation and climatic changes in the lacustrine deposits of the Rubielos de Mora Basin (Teruel, NE Spain), Palaeogeogr. Palaeoclimatol. Palaeoecol., 250, 103113, 2007

Kaneps, A. G.: Gulf Stream: velocity fluctuations during the late Cenozoic, Science, 204, 297-301, 1981.

Kotthoff, U., Müller, U. C., Pross, J., Schmiedl, G., Lawson, I. T., van de Schootbrugge, B., and Schulz, H.: Late Glacial and Holocene vegetation dynamics in the Aegean region: An integrated view based on pollen data from marine and terrestrial archives, Holocene, 18, 1019-1032, 2008a.

Kotthoff, U., Pross, J., Müller, U. C., Peyron, O., Schmiedl, G., Schulz, H., and Bordon, A.: Timing and characteristics of terrestrial vegetation change in the NE Mediterranean region associated with the formation of marine Sapropel S1: A land-sea correlation, Quat. Sci. Rev., 27, 832-845, 2008b.

Krutzsch, W.: Atlas der mittel- und jungtertiären dispersen Sporenund Pollen- sowie der Mikroplanktonformen des nördlichen Mitteleuropa, Lieferung II, VEB Deutscher Verlag der Wissenschaften, Berlin, 141 pp., 1963a.
Krutzsch, W.: Atlas der mittel- und jungtertiären dispersen Sporenund Pollen- sowie der Mikroplanktonformen des nördlichen Mitteleuropa, Lieferung III, VEB Deutscher Verlag der Wissenschaften, Berlin, 128 pp., 1963 b.

Krutzsch, W.: Atlas der mittel- und jungtertiären dispersen Sporenund Pollen- sowie der Mikroplanktonformen des nördlichen Mitteleuropa, Lieferung IV und V, VEB Deutscher Verlag der Wissenschaften, Berlin, 232 pp., 1967.

Krutzsch, W.: Atlas der mittel- und jungtertiären dispersen Sporenund Pollen- sowie der Mikroplanktonformen des nördlichen Mitteleuropa, Lieferung VII, VEB Deutscher Verlag der Wissenschaften, Berlin, 175 pp., 1970.

Krutzsch, W.: Atlas der mittel- und jungtertiären dispersen Sporenund Pollen- sowie der Mikroplanktonformen des nördlichen Mitteleuropa, Lieferung VI, VEB Deutscher Verlag der Wissenschaften, Berlin, 234 pp., 1971.

Lacourse, T., Mathewes, R. W., and Fedje, D.W.: Paleoecology of late-glacial terrestrial deposits with in situ conifers from the submerged continental shelf of western Canada, Quat. Res., 60, 180 188, 2003.

Larsson, L. M., Dybkjaer, K., Rasmussen, E. S., Piasecki, S., Utescher, T., and Vajda, V.: Miocene climate evolution of northern Europe: A palynological investigation from Denmark, Palaeogeogr. Palaeoclimatol. Palaeoecol., 309, 161-175, 2011.

Leopold, E. B., Liu, G., and Clay-Poole, S.: Low-biomass vegetation in the Oligocene?, in: Eocene-Oligocene climatic and biotic evolution, edited by: Prothero, D. A. and Bergren, W. A., Princeton, NJ, Princeton University Press, 399-420, 1992.

Liu, Z., Pagani, M., Zinniker, D., DeConto, R., Huber, M., Brinkhuis, H., Shah, S. R., Leckie, R. M., and Pearson, A.: Global cooling during the Eocene-Oligocene climate transition, Science, 323, 1187-1190, 2009.

McAndrews, J. H., Berti, A. A., and Norris, G.: Key to the Quaternary Pollen and Spores of the Great Lakes Region. Life Science Miscellaneous Publications, Royal Ontario Museum, Toronto, 65 pp., 1973.

McCartan, L., Tiffney, B. H., Wolfe, J. A., Ager, T. A., Wing, S. L., Sirkin, L. E., Ward, L. W., and Brooks, J.: Late Tertiary floral assemblages from upland gravel deposits of the southern Maryland Coastal Plain, Geology, 18, 311-314, 1990.

McCarthy, F. M. G. and Mudie, P.: Oceanic pollen transport and pollen:dinocyst ratios as markers of late Cenozoic sea level change and sediment transport, Palaeogeogr. Palaeoclimatol. Palaeoecol., 138, 187-206, 1998.

McCarthy, F. M. G., Gostlin, K. E., Mudie, P. J., and Scott, D. B.: Synchronous palynological changes in early Pleistocene sediments off New Jersey and Iberia, and a possible paleoceanographic explanation, Palynology, 24, 63-77, 2000.

McCarthy, F. M. G., Gostlin, K. E., Mudie, P. J., and Pedersen, R. O.: The palynological record of terrigenous flux to the deep sea: late Pliocene-Recent examples from ${ }^{41} \mathrm{~N}$ in the abyssal Atlantic and Pacific oceans. Rev. Palaeobot. Palynol., 128, 81-95, 2004

McCarthy, F. M. G., Katz, M., Kotthoff, U., Browning, J., Miller, K., Zanatta, R., Williams, R., Drljepan, M., Hesselbo, S. P., Bjerrum, C., and Mountain, G.: Eustatic control of New Jersey margin architecture: palynological evidence from IODP Expedition 313, Geosphere, 9, doi:10.1130/GES00853.1, 2013. 
Miller, K. G. and Sugarman, P. J.: Correlating Miocene sequences in onshore New Jersey boreholes (IODP Leg 150X) with global $\delta^{18} \mathrm{O}$ and Maryland outcrops, Geology, 23, 747-750, 1995.

Miller, K. G. and Mountain, G. S., Leg 150 Shipboard Party, members of the New Jersey Coastal Plain drilling project.: Drilling and dating New Jersey Oligocene-Miocene Sequences: Ice volume, global sea level, and Exxon records, Science, 271, 10921095, 1996.

Miller, K. G., Fairbanks, R. G., and Mountain, G. S.: Tertiary oxygen isotope synthesis, sea level history, and continental margin erosion, Paleoceanography, 2, 1-19, 1987.

Miller, K. G., Wright, J. D., and Fairbanks, R. G.: Unlocking the Ice House: Oligocene-Miocene Oxygen Isotopes, Eustasy, and Margin Erosion, J. Geophys. Res., 96, 6829-6848, 1991.

Miller, K. G., Kominz, M. A., Browning, J. V., Wright, J. D., Mountain, G. S., Katz, M. E., Sugerman, P. J., Cramer, B. S., ChristieBlick, N., and Pekar, S. F.: The Phanerozoic record of global sea-level change, Science, 310, 1293-1298, 2005.

Miller, K. G., Mountain, G. S., Wright, J. D., and Browning, J. V.: A 180-million-year record of sea level and ice volume variations from continental margin and deep-sea isotopic records, Oceanography, 24, 40-53, 2011.

Miller, K. G, Browning, J. V., Mountain, G. S., Bassetti, M. A., Monteverde, D., Katz, M. E., Inwood, J., Lofi, J., and Proust, J.N.: Sequence boundaries are impedance contrasts: Core-seismic integration of Oligocene-Miocene sequences, New Jersey shallow shelf, Geosphere, 9, 1257-1285, 2013.

Mosbrugger, V. and Utescher, T.: The coexistence approach - a method for quantitative reconstructions of Tertiary terrestrial palaeoclimate data using plant fossils, Palaeogeogr. Palaeoclimatol. Palaeoecol., 134, 61-86, 1997.

Mosbrugger, V., Utescher, T., and Dilcher, D. L.: Cenozoic continental climatic evolution of Central Europe, P. Natl. Acad. Sci. USA, 102, 1-6, 2005.

Mountain, G. S., Proust, J.-N., McInroy, D., Cotterill, C, and the Expedition 313 scientists: Proceedings of Integrated Ocean Drilling Program, 313, Tokyo (Integrated Ocean Drilling Program Management International, Inc.), 2010.

Mudie, P. J.: Pollen distribution in recent marine sediments, eastern Canada, Can. J. Earth Sci., 19, 729-747, 1982.

Mudie, P. J. and McCarthy, F. M. G.: Late Quaternary pollen transport processes, western North Atlantic: Data from box models, cross-margin and N-S transects, Mar. Geol., 118, 79-105, 1994.

Natural Resources Canada: Climatic Range map (1971-2000 scenario)/climatic profile: Canadian Forest Service, Sault Ste. Marie, http://planthardiness.gc.ca/index.pl?lang=enandm= 13andp=1, last access: May, 2012.

Nichols, D. J.: North American and European species of Momipites ("Engelhardtia") and related genera, Geosci. Man., 7, 103-117, 1973.

Nichols, D. J. and Brown, J. L.: Palynostratigraphy of the Tullock Member lower Paleocene of the Fort Union Formation in the Powder River Basin Montana and Wyoming. Evolution of sedimentary basins Powder River Basin, US Geological Survey Bulletin 1917, F1-F35, 10 plates, 1992.

Oboh, F. E., Jaramillo, C. A., and Reeves Morris, L. M.: Late Eocene-Early Oligocene paleofloristic patterns in southern Mississippi and Alabama, US Gulf Coast, Rev. Palaeobot. Palynol., 91, 23-34, 1996.
Pagani, M., Arthur, M. A., and Freeman, K. H.: Miocene evolution of atmospheric carbon dioxide, Paleoceanography, 14, 273-292, 1999.

Pagani, M., Zachos, J. C., Freeman, K. H., Tipple, B., and Bohaty, S.: Marked decline in atmospheric carbon dioxide concentrations during the Paleogene, Science, 309, 600-603, 2005.

Pagani, M., Caldeira, K., Berner, R., and Beerling D. J.: The role of terrestrial plants in limiting atmospheric $\mathrm{CO}_{2}$ decline over the past 24 million years, Nature, 460, 85-88, 2009.

Pazzaglia, F. J. and Brandon, M. T.: Macrogeomorphic evolution of the post-Triassic Appalachian mountains determined by deconvolution of the offshore basin sedimentary record, Basin Res., 8, 255-278, 1996.

Pazzaglia, F. J., Robinson, R. A. J., and Traverse, A.: Palynology of the Bryn Mawr Formation (Miocene): insights on the age and genesis of the Middle Atlantic margin fluvial deposits, Sediment. Geol., 108, 19-44, 1997.

Pekar, S. F. and DeConto, R. M.: High-resolution ice-volume estimates for the early Miocene: Evidence for a dynamic ice sheet in Antarctica, Palaeogeogr. Palaeoclimatol. Palaeoecol., 231, 101109, 2006.

Pinet, P. R., Popenoe, P., and Neilligan, D. F.: Gulf Stream: reconstruction of Cenzoic clow patterns over the Blake Plateau, Geology, 9, 266-270, 1981.

Poag, C. W. and Sevon, W. D.: A record of Appalachian denudation in postrift Mesozoic and Cenozoic sedimentary deposits of the U.S. Middle Atlantic Continental Margin, Geomorphology, 2, 119-157, 1989.

Pross, J., Klotz, S., and Mosbrugger, V.: Reconstructing palaeotemperatures for the Early and Middle Pleistocene using the mutual climatic range method based on plant fossils, Quat. Sci. Rev., 19, 1785-1799, 2000.

Pross, J., Contreras, L., Bijl, P. K., Greenwood, D. R., Bohaty, S. M., Schouten, S., Bendle, J. A., Röhl, U., Tauxe, L., Raine, J. I., Huck, C. E., van de Flierdt, T., Jamieson, S. S. R., Stickley, C. E., van de Schootbrugge, B., Escutia, C., Brinkhuis, H., and IODP Expedition 318 Scientists: Persistent near-tropical warmth on the Antarctic continent during the early Eocene epoch, Nature, 488, 73-77, 2012.

Quaijtaal, W., Donders, T. H., Persico, D., and Louwye, S.: Characterising the middle Miocene Mi-events in the Eastern North Atlantic realm: A first high-resolution marine palynological record from the Porcupine Basin, Palaeogeogr. Palaeoclimatol. Palaeoecol., 399, 140-159, 2014.

Rachele, L. D.: Palynology of the Legler Lignite: a deposit in the Tertiary Cohansey Formation of New Jersey, USA, Rev. Palaeobot. Palynol., 22, 225-252, 1976.

Reichgelt, T., Kennedy, E. M., Mildenhall, D. C., Conran, J. G., Greenwood, D. R., and Lee, D. E.: Quantitative palaeoclimate estimates for Early Miocene southern New Zealand: evidence from Foulden Maar, Palaeogeogr. Palaeoclimatol. Palaeoecol., 378, 36-44, 2013.

Rich, F. J., Pirkle, F. L., and Arenberg E.: Palynology and paleoecology of strata associated with the Ohoopee River dune field, Emanuel County, Georgia, Palynology 26, 239-256, 2002.

Schlitzer, R.: Ocean Data View, http://odv.awi.de, 2011.

Shackleton, N. J. and Kennett, J. P.: Paleotemperature history oft he Cenozoic and initiation of Antarctic glaciation: Oxygen and car- 
bon isotopic analyses in DSDP sites 277, 279, and 281, in: Initial reports of the Deep Sea Drilling Project, 29, 743-755, 1975.

Stockmarr, J.: Tablets with spores used in absolute pollen analysis, Pollen et Spores, 13, 615-21, 1971.

Strömberg, C. A. E.: Decoupled taxonomic radiation and ecological expansion of open-habitat grasses in the Cenozoic of North America, P. Natl. Acad. Sci. USA, 102, 11980-11984, 2005.

Stults, D. Z., Axsmith, B. J., and Liu, Y.-S.: Evidence of white pine (Pinus subgenus Strobus) dominance from the Pliocene Northeastern Gulf of Mexico Coastal Plain, Palaeogeogr. Palaeoclimatol. Palaeoecol., 287, 95-100, 2010.

Taylor, L. L., Leake, J. R., Quirk, J., Hardy, K., Banwart, S. A., and Beerling, D. J.: Biological weathering and the long-term carbon cycle: integrating mycorrhizal evolution and function into the current paradigm, Geobiology, 7, 171-191, 2009.

Thompson, R. S., Anderson, K. H., and Bartlein, P. J.: Atlas of relations between climatic parameters and distributions of important trees and shrubs in North America. U.S. Geological Survey Professional Paper $1650 \mathrm{~A}$ and B. Online Version 1.0, 14 December 1999, http://pubs.usgs.gov/pp/p1650-a/, 1999.

Thompson, R. S., Anderson, K. H., Bartlein, P. J., and Smith, S. A.: Atlas of relations between climatic parameters and distributions of important trees and shrubs in North America; additional conifers, hardwoods, and monocots. US Geological Survey Professional Paper $1650 \mathrm{C}$, http://pubs.er.usgs.gov/publication/ pp1650C, p. 386, 2000.

Thompson, R. S., Anderson, K. H., Pelltier, R. T., Strickland, L. E., Bartlein, P. J., and Shafer, S. L.: Quantitative estimation of climatic parameters from vegetation data in North America by the mutual climatic range technique, J. Quat. Sci., 51, 18-39, 2012.

Traverse, A.: Palynofloral geochronology of the Brandon Lignite of Vermont, USA. Rev. Palaeobot. Palynol., 82, 265-297, 1994.
Traverse, A.: Paleopalynology. Second edition. In: Topics of Geobiology, 28. 813 pp., 2008.

Utescher, T., Djordjevic-Milutinovic, D., Bruch, A., and Mosbrugger, V.: Palaeoclimate and vegetation change in Serbia during the last $30 \mathrm{M}$, Palaeogeogr. Palaeoclimatol. Palaeoecol., 253, 141152, 2007.

Utescher, T., Ivanov, D., Harzhauser, M., Bozukov, V., Ashraf, A. R., Rolf, C., Urbat, M., and Mosbrugger, V.: Cyclic climate and vegetation change in the Late Miocene of Western Bulgaria, Palaeogeogr. Palaeoclimatol. Palaeoecol., 272, 99-114, 2009.

Wade, B. S. and Pälike, H.: Oligocene climate dynamics. Paleoceanography, 19, PA4019, doi:10.1029/2004PA001042, 2004.

Willis, K. J. and McElwain, J. C.: The Evolution of Plants. Oxford University Press, Oxford, 2002.

Wolfe, J. A.: Climatic, floristic, and vegetational changes near the Eocene/Oligocene boundary in North America, in: EoceneOligocene climatic and biotic evolution, edited by: Prothero, D. A. and Bergren, W. A., Princeton, NJ, Princeton University Press, 421-436, 1992.

Wright, J. D. and Miller, K. G.: Early and Middle Miocene stable isotopes: implications for deepwater circulation and climate, $\mathrm{Pa}-$ leoceanography, 7, 357-389, 1992.

Zachos, J., Pagani, M., Sloan, L., Thomas, E., and Billups, K.: Trends, rhythms, and aberrations in global climate $65 \mathrm{Ma}$ to present, Science, 292, 686-693, 2001a.

Zachos, J. C., Shackleton, N. J., Revenaugh, J. S., Pälike, H., and Flower, B. P.: Climate response to orbital forcing across the Oligocene-Miocene boundary, Science, 292, 274-278, 2001 b.

Zachos, J. C., Dickens, G. R., and Zeebe, R. E.: An early Cenozoic perspective on greenhouse warming and carbon-cycle dynamics, Nature, 451, 279-283, 2008. 